\title{
The Model of Participating, Payable, Profitable, Potent Insured Education System-4Ps IESM
}

\author{
Seniha Çelikhan \\ Gebze High Technology Institute, Kocaeli, Turkey
}

\begin{abstract}
In the field of education, there is a need for a financing system which is affordable, yet effective, as well as profitable, and is based on user participation. This need was the main reason the author has designed the model named "Insured Education System Model-IESM". The IESM is based on the principle that expenditures incurred at each stage of educational attainment should not be burdened upon the person himself/herself. There should be insurance companies willing to cover the educational expenditures of the buyers. The suggested IESM model also creates an auto-control mechanism within the financing system through which insurance companies, educational institutions (buyers), and households will gain benefits. Furthermore, the IESM will increase the quality of service within the overall educational system, and create employment, as well as eliminating the number of school drop outs. The system will bring a significant decrease in the cost of the service. This study presents the results of the analyses on the data collected by the author on the perception of the proposed Insured Education System Models through surveys conducted in selected schools in Istanbul. The survey is unique in a sense that for the first time in literature such a model is suggested and the perception of relevant stake holders are tested through a questionnaire of 42 questions. The results show that there is an approval rate of more than 50\% regarding to the IESM. And the frequency analysis suggests that the IESM is an applicable model.
\end{abstract}

Keywords: insurance, education, user, competition, auto-control, profit

\section{Introduction}

In this paper, firstly educational problems will be briefly presented, and then the rationale and the methodology of the study are explained. After introductory information about the questionnaire used in this study, the results of the frequency analysis and cross tabulation are discussed.

\section{Overview of the Problems of Education in Turkey}

As dictated by the Basic Law of National Education which stipulates that the right to receive education is not a prerogative belonging to anybody, or any family, or any community, or any social class, education service must be supplied to all on equal terms. According to the aforementioned law, this equality can only be broken by the individual in their choice of various programs and schools depending on their interest, ability, and capacity.

However, there is an imbalance in the distribution of educational institutions of preschool and secondary

Seniha Çelikhan, Ph.D., Professor, City and Regional Planning, Gebze High Technology Institute.

Correspondence concerning this article should be addressed to Seniha Çelikhan, Gebze Yüksek Teknoloji Enstitüsü, Şehir ve Bölge Planlama Bölümü P.K.: 141, 41400 Gebze/Kocaeli, Turkey. E-mail: celikhan@gyte.edu.tr. 
school levels across regions due to inter regional differences in demand for education. It is argued that in the distribution of educational institutions neither manpower requirements, nor youth's interest and request are taken into account (State Planning Organization (SPO), the special commission's report of VII five-year development plan). The population growth rate in Turkey in the year 2000 is $1.4 \%$, and the higher the population growth rate, the bigger the ratio of the dependents (the age group of zero to 14 years) to the total population.

The schooling rate in $1994-1995$ school years is: $5.1 \%$ in preschool level; $89.8 \%$ in elementary school level; $53 \%$ in secondary school level; and $26.7 \%$ in university level. At the elementary school level in 2001-2002 school days, Ağr Province is recorded to have the schooling rate at $63.6 \%$, while Gaziantep Province has the highest at $100 \%$. In the same year, the lowest schooling rate at the secondary school level is recorded as $11.23 \%$ in Muş province, and the highest as $67.93 \%$ in Ankara (TUIK).

In the year 2000 , only $3.6 \%$ of the gross national product of Turkey is allocated to education, which is higher than $1.79 \%$ recorded in 1989 . Due to lack of resources, the objective set by the national education law cannot be achieved. At this point, involvement of the families becomes an issue. Universities in Turkey are designed to be self sufficient with regard to income generation, yet eligible to state fund when their own resources are insufficient. However, today $90 \%$ the financial needs of universities are met by the government budget. And because of the insufficiency of the state budget, universities do not make as much progress as expected of them. Therefore, the idea of students sharing the burden of education is perceived positively (SPO, the special commission's report of VII five-year development plan).

In the year $2002,64.81 \%$ of all educational expenditure is paid by the central government, and $32.85 \%$ is by households. The remaining $2.34 \%$ is undertaken by natural persons or legal identities $(1.55 \%)$, by local governments $(0.70 \%)$, and by international resources $(0.09 \%)$. The total amount spent on education in 2002 is 20,155,207,668,725,300 TL.

In 2002, elementary schools receive the highest share of allocation in the total of education spending with a $38.01 \%$, which is followed by universities with $32.49 \%$, then by secondary schools with $24.69 \%$. Preschool institutions and distant learning program received less than one percent $(0.41 \%$ and $0.19 \%$ respectively). While non-formal education institutions received a $1.85 \%$ share, the remaining $2.36 \%$ is allocated to the other educational expenditure.

In terms of the spending per student at each education level in 2002, the average for preschool is $\$ 171$, which shows a striking difference in public $(\$ 102)$ versus private schools $(\$ 2,363)$. As for the elementary school, the average is $\$ 488$ with public school spending at $\$ 470$, and private school spending at $\$ 1,639$. The average value for the high school level is $\$ 962$, which goes down to $\$ 940$ in public schools, and rises up to $\$ 1,741$ in private schools. Vocational high schools spend more on each student with an average of $\$ 1,325$, which goes down to $\$ 1,324$ in public schools and rises up to $\$ 2,642$. At the university level (associate degree, bachelor's degree, post graduate, and Ph.D.), the average spending is $\$ 2,254$.

The average household size in Turkey, in 1998, is 4.3 persons, which decreases to four in urban areas, and increases to 4.9 in rural areas. There are five or more people in two-fifths of all households. The size of household has a direct impact on per capita amount of the household resources.

Approximately 909,000 people in Turkey are estimated to be under hunger threshold, whereas 17,991,000 more are estimated to be under the poverty line in 2004. These estimations are based on monthly hunger threshold of $182,000,000 \mathrm{TL}$, and poverty threshold of 429,000,000 TL for a household of four people. 
According to these figures, the number of those who are under hunger threshold remained the same in 2004 as in 2003 , when the estimation put the number at $1.29 \%$ of the population. And there was an improvement on poverty figures which went down from $28.12 \%$ in 2003 to $25.6 \%$ in 2004 .

In 2006, the average gross wage is 1,238 TL monthly in the first quarter of the year. The highest gross wage is recorded 4,999 TL monthly in high risk industries such as coking coal and petroleum refinery. The gross national product in 2004 is recorded as $\$ 4,172$ (TUIK).

The abandonment cost is important in education, which the family gave up during the education of their children, who would otherwise contribute to the total income of the household.

\section{Rationale}

The figures set forth above illustrate that: the resources allocated to the national education are not adequate; the educational needs of the entire population cannot be met by the state budget; the supply is insufficient to meet the demand; therefore, education opportunity is not offered on equal terms, and not everybody can benefit from these opportunities equally. In parallel with all these, families are compelled to send their children to private prep courses in order for them to compete for better schools. These courses lead to an exponential increase in the cost of education families have pay. The figures explained in the previous section also show that: there is a huge difference in cost between private and public school spending; students from underprivileged households are deprived of the opportunity to attain education up their desired level; demand for education differs along the line of socio economic levels in the society; kindergartens are in low demand except for the compulsory education institutions; private schools cannot flourish within the current education system; and student cannot attain the education they desire.

As stated in the 8th Five-Year Progress Plan Report, it is compulsory for households and students to participate in education. Therefore, the "Participating, Payable, Profitable, Prepotent Insured Education System Model" is developed with the aim of eliminating inequality in education by creating means for underprivileged households and/or students to access educational opportunities unlimitedly as well as enabling them to pay for it affordably.

\section{Methodology}

In this study, which draws on the perception that the Participating, Payable, Profitable, Potent Insured Education System is likely to be accepted by the families who are already under the burden of education cost of their children, therefore is likely to be applicable in practice, a descriptive and qualitative research method is employed. A five-point-Likert-Scales based survey is prepared to measure approval rate of the Köye-SES Model among households/students, and teachers. The results show that the model received a high approval level.

The surveys are conducted in preschool, elementary and secondary school levels in selected districts of Istanbul, namely, Kadıköy, Beyoğlu, Fatih, Adalar, and Tuzla. The research units are households who have children attending in these schools, and their teachers. It is assumed that the selected districts have appropriate representation of the target groups. The questionnaire is pre-tested for reliability and validity by a group of 15 people at the Gebze Institute of Technology, and revised accordingly. In addition to descriptive information about respondents, there are 42 questions in the survey aiming at measuring the approval rate of the model.

The surveys are sent to the schools through their corresponding District Education Directorates under the permit of the Provincial Directorate of National Education. During this process, the questionnaire is controlled by the inspectors of the Provincial Directorate of National Education, and a permit document is issued. Then, a 
total number of 4,000 surveys are delivered to the District Education Directorates along with the permit to be forwarded to the schools. Each school principal was in charge of conducting the survey making sure that the questions were answered by a teacher and three households for each independent variable - namely, "number of children", "education level", "income level", and "occupation"- totaling up to 13 units from each school. Then the principals sent back the surveys to the District Education Directorates. Total number of surveys which were sent back is 2,369 .

The return rate of the survey is $60 \%$. Statistical analyses on the data from the surveys are done via SPSS program. The data are examined through frequency analyses, cross tabulation, descriptive distribution of the variables. Relationships between the variables are tested using Ki-Square test. And a variance analysis is conducted on the answers by the variables. Later, the 42 questions are grouped under four components through factor analysis, and then the relationship between the four components and the variables are examined. This paper presents the results from frequency and cross tabulation analyses.

\section{The Questionnaire for Insured Education System}

The questionnaire is designed as to provide information on the proposed education model, its purpose and how it would be implemented in practice, on the first page, and the 42 questions on the next. Following is the purpose and the implementing suggestions of the model as it is presented on the questionnaire, which is followed by the summary table of responses and their average values.

\section{Purpose of the Insured Education System}

The purpose of the Insured Education System is: (1) to establish a system which would secure the future of any child by financing their education cost from the first day of their life, or from their current educational level by means of an insurance plan paid by the parents, or by the students themselves, or by a third party institution through an affordable payment plan extended over a period of time; (2) to include everyone with children to share the burden of education cost at the same rate; (3) to eliminate inequality in education; (4) to enable students finance their own education through loans; (5) to give each student a chance to go to a school of his/her own choice up to their targeted level; (6) to eliminate inefficiency of the education institutions caused by insufficient number of students; (7) to establish interactions between educational institutions and insurance companies to provide quality education at an affordable cost; and (8) to ensure that insurance companies give investment credits for the development of the areas in which they are located.

\section{Implementation of the Insured Education System}

All educational institutions, private or public, including kindergartens, elementary and secondary schools, high schools, and universities, even the graduate programs, as well as all insurance companies can participate in the insured education system as long as they satisfy pre-determined minimum standards with regard to their capital, service, and equipment. Educational institutions and insurance companies can make agreements among themselves. Insurance companies develop single or multiple insurance packages in accordance with each stage of the education, among which students or their parents can buy the one that fits the best for their need and payment capacity.

Public schools can be privatized in this insured education system, or operated by the state within the framework of the education insurance system. Families can send their children to any public or private school of their choice within the framework of the insurance package they purchase. Education fees are paid to the customers' schools by the insurance companies. In order to attract more customers, insurance companies 
develop more competitive insurance packages. Educational institutions take measures to improve their quality standards, all the while reducing the fees to sign contracts with as much insurance company as possible, so that they can compete in the student market.

The insured education system stipulates that, while it calls for cooperation among insurance companies, educational institutions and families of students, the system also makes sure that each of these groups creates an auto-control system on one another based on profit maximization principle. Therefore, the system will improve itself towards a higher quality, cheaper prize, and increased number of students. In this way, students will benefit from improved quality standards and lowered prizes, while educational institutions and insurance companies will benefit from increased number of students and customers. In other way, the more students take part in this system the better the quality of education at a cheaper prize, and vice versa.

While minimizing the difference in quality among educational institutions, the insured education system will help eliminate class differences in educational attainment through funds and loans. Thus, it will provide students from low income and deprived families with an opportunity to realize their constitutional right to attain education on equal terms with the others. Those families who choose not to purchase an insurance package will pay the education fees to the schools directly. Access to university education will be conditioned upon grades received in high school with regard to the chosen field of study.

\section{Frequency Analysis and the Results From Cross Tabulation Analyses}

In the analysis section of the study, firstly, frequency analysis and cross tabulation is created, and then proportional distribution of the variables is shown:

A total of 2,369 surveys conducted on the Insured Education System Model. Of these, 5.2\% (a total of 110 schools) are done in private schools, whereas $95.4 \%$ (a total of 2,259 schools) are in public schools. In districts with higher number of schools, there are more surveys conducted, thus 894 surveys (37.5\% of the total) are done in Kadıköy, which is the highest in this regard.

Results from the frequency analyses on proportional distribution of the respondents by districts with regard to family size, education level, income range, and occupation are show below.

\section{Proportional Distribution of Family Size by Districts}

The ratio of families without children and those with one, two, and four children is the highest in Kadiköy, whereas the ratio of families with three children and those with five or more children is the highest in Fatih. Analyzing districts with regard to family size ratios, we can see that in all districts included in this study, the ratio of families with two children is higher than the other family size categories. The ratio of families without children is the lowest in Fatih, and highest in Adalar. Similarly, the ratio of families with one child is the highest in Adalar, and lowest in Fatih. The ratio of families with two children is the highest in Adalar, and lowest in Beyoğlu. The ratio of families with three children is the highest in Fatih, and lowest in Adalar. The ratio of families with four children is the highest in Fatih, and lowest in Adalar. The ratio of families with five or more children is the highest in Tuzla, then Fatih, and the lowest in Adalar, then Kadıköy. In sum, while Fatih stands out as the district with larger family sizes, Adalar has the lowest family size.

\section{Proportional Distribution of Education Level by Districts}

The ratio of those who did not receive education is the highest in Kadıköy, and the lowest in Adalar. The ratio of those who finished elementary school is highest in Fatih, lowest in Adalar. The ratio of those who 
finished secondary school is highest in Kadıköy, and the lowest in Adalar. The ratio of high school graduates is highest in Kadıköy, lowest in Adalar. The ratio of University graduates is highest in Kadıköy, lowest in Adalar. Looking at the district by the ratio of education level we can see that in Tuzla, and Adalar, the ratio of university graduates is the highest, whereas in Kadıköy, and Beyoglu the ratio of high school graduates is the highest. The ratio of those who finished only elementary school is the highest in Fatih district.

\section{Proportional Distribution of Income Level by Districts}

The ratio of those who do not specify their income level is the highest in Kadiköy, and the lowest in Adalar. The ratio of income level 150-1,000 YTL is the highest in Kadıöy, then Fatih, and lowest in Adalar. The ratio of income level 1,100-2,500 YTL is the highest in Kadıköy, and the lowest in Adalar. The ratio of income level 2,600-5,000 YTL is the highest in Kadıköy, and lowest in Tuzla (Because we do not have this category in Adalar). The ratio of income level 5,000- YTL is the highest in Kadıköy, and Beyoğlu and lowest in Tuzla (Because we do not have this category in Adalar). Analyzing districts by income level values, we can see that the ratio of families who are in 150-1,000 YTL income range is the highest in Tuzla, Kadıköy, Beyoğlu, Fatih, and Adalar. The proportional distribution of occupation by districts shows that the ratio of workers is the highest in Fatih and lowest in Adalar. The ratio of unemployed, retired, housewife, civil servant, educator, employer, and self-employed are the highest in Kadıköy and lowest in Adalar.

\section{Proportional Distribution of Occupation by Districts}

The ratio of worker is the highest in Tuzla, whereas the ratio of employer is the lowest. The ratio of self-employed is the highest in Kadıköy, Beyoglu, and Fatih, whereas the ratio of employer is the lowest. In Adalar, the ratios of self-employed and civil servant are the highest, whereas the ratio of employer is the lowest.

\section{Proportional Distribution of Family Size by Occupation}

The ratio of families without children is higher among those who are classified as unemployed, retired, and housewife, whereas the ratio of families with two children is higher among workers, civil servants, educators, employers, and self-employers. And the ratios of families with one or more children are higher among self-employed category.

\section{Proportional Distribution of Income Level by Family Size}

The ratio of those who do not specify their income level is higher among families without children, whereas the ratios of the other income level categories (150-1,000 YTL, 1,100-2,500 YTL, 2,500-5,000 YTL, and 5,000+) are higher in families with two children.

\section{Proportional Distribution of Family Size by Income Level}

The ratios of all family size categories are higher in income level 150-1,000 YTL. Proportional distribution of education level by family size: The ratio of those who did not receive education is higher among families without children, whereas the ratios of the other education level categories (elementary, secondary, high school, university and higher) are higher in families with two children.

\section{Proportional Distribution of Family Size by Education Level}

The ratio of those families without children or with only one child is higher among those who received college education or more. The ratio of families with two or three children is higher among high school graduates, whereas the ratio of families with four or more children is higher among those who finished only elementary school. 


\section{Proportional Distribution of Education by Income Level}

The ratio of those who did not receive education is higher among those who do not specify their income level, whereas the ratios of the other education categories are higher in income level 150-1,000 YTL.

\section{Proportional Distribution of Income by Education Level}

The ratio of those who do not specify their income level is higher among those who did not receive education, whereas the ratio of income levels 150-1,000 YTL is higher among those who finished elementary school. And the ratios of the upper three income levels (1,100-2,500 YTL, 2,500-5,000 YTL, and 5,000+) are higher among those who received college education or more.

\section{Proportional Distribution of Income by Occupation}

The ratio of those who do not specify their income level is higher among unemployed, retired and housewives, whereas the ratio of income level 150-1,000 YTL is higher among workers. And the ratios of the upper three income levels (1,100-2,500 YTL, 2,500-5,000 YTL, and 5,000+) are higher in self-employed category.

\section{Proportional Distribution of Occupation by Income}

The ratio of those who are classed as unemployed, retired, and housewife is higher in "no specific income level" group, whereas the ratio of worker, civil servant, educator, and self-employed is higher in income level of 150-1,000 YTL. The ratio of employer is higher in income level of 1,100-2,500 YTL.

Table 1 shows the proportional distribution of responses to the questionnaire. As can be seen from the table, proposal of Köye-SES model is viewed positively with an average value of more than 3 in all questions except for the sixth and the first two questions, which are stated as negative questions.

Table 1

Results of Inquiry for the Insured Education System Model

\begin{tabular}{|c|c|c|c|c|c|c|}
\hline $\begin{array}{l}\text { To which extent you agree with the opinion that the } \\
\text { following developments occur with the insurance of } \\
\text { education }\end{array}$ & $\begin{array}{l}\text { Average-by } 5 \\
\text { parameter of } \\
\text { scale values }\end{array}$ & $\begin{array}{l}\text { Definitely } \\
\text { disagree }\end{array}$ & Disagree & Ambivalent & Agree & $\begin{array}{l}\text { Definitely } \\
\text { agree }\end{array}$ \\
\hline 1. Public schools cannot participate in this system & 2.60 & 26.5 & 26.1 & 19.1 & 17.8 & 10.4 \\
\hline 2. Public schools can be transferred to private institutions & 2.56 & 27.8 & 27.0 & 15.4 & 20.7 & 9.0 \\
\hline 3. Public schools can be operated like private schools & 3.09 & 18.7 & 19.6 & 12.2 & 32.7 & 16.8 \\
\hline $\begin{array}{l}\text { 4. In education public versus private school dichotomy can } \\
\text { be eradicated }\end{array}$ & 3.42 & 11.3 & 16.7 & 13.8 & 35.2 & 23.0 \\
\hline 5. Private schools can become widespread & 3.01 & 14.5 & 23.1 & 20.7 & 30.2 & 11.5 \\
\hline 6. Demand for public schools might decrease & 2.82 & 15.9 & 30.8 & 18.4 & 25.3 & 9.6 \\
\hline 7. All student can attain the school of his/her choice & 3.58 & 9.1 & 13.7 & 12.6 & 39.7 & 24.9 \\
\hline 8. Quality becomes important when choosing school & 3.74 & 7.8 & 9.7 & 11.8 & 41.9 & 28.8 \\
\hline 9. Kindergarten education can become widespread & 3.78 & 6.6 & 9.2 & 12.9 & 41.6 & 29.6 \\
\hline 10. The students can receive more schooling & 3.28 & 12.2 & 16.3 & 18.6 & 36.9 & 16.0 \\
\hline $\begin{array}{l}\text { 11. All student can have the opportunity to reach his/her } \\
\text { educational attainment of his/her desire }\end{array}$ & 3.60 & 8.4 & 12.7 & 14.1 & 40.2 & 24.6 \\
\hline $\begin{array}{l}\text { 12. Occupation and specialization rate of the youth can } \\
\text { increase }\end{array}$ & 3.75 & 6.1 & 10.6 & 13.5 & 42.0 & 27.8 \\
\hline $\begin{array}{l}\text { 13. The proposed system can eliminate existing educational } \\
\text { problems }\end{array}$ & 3.47 & 8.6 & 13.6 & 20.1 & 37.7 & 20.1 \\
\hline 14. The schools can adopt more flexible educational programs & 3.51 & 7.2 & 13.7 & 19.1 & 41.2 & 18.8 \\
\hline 15. The quality of education can rise & 3.73 & 7.1 & 10.4 & 12.4 & 42.2 & 27.9 \\
\hline 16. Equality in education can be achieved & 3.60 & 8.7 & 13.6 & 13.3 & 37.4 & 27.1 \\
\hline
\end{tabular}


(Table 1 continued)

\begin{tabular}{|c|c|c|c|c|c|c|}
\hline $\begin{array}{l}\text { To which extent you agree with the opinion that the } \\
\text { following developments occur with the insurance of } \\
\text { education }\end{array}$ & $\begin{array}{l}\text { Average-by } 5 \\
\text { parameter of } \\
\text { scale values }\end{array}$ & $\begin{array}{l}\text { Definitely } \\
\text { disagree }\end{array}$ & Disagree & Ambivalent & Agree & $\begin{array}{l}\text { Definitely } \\
\text { agree }\end{array}$ \\
\hline $\begin{array}{l}\text { 17. Participation rate of households, institutions and } \\
\text { individuals in financing of education can increase }\end{array}$ & 3.39 & 7.0 & 13.8 & 26.1 & 39.4 & 13.7 \\
\hline $\begin{array}{l}\text { 18. An auto-control mechanism can be established among } \\
\text { educators, insurers, and users (students) of the system }\end{array}$ & 3.35 & 6.8 & 13.7 & 28.4 & 40.0 & 11.1 \\
\hline $\begin{array}{l}\text { 19. Insurers and users (students) can have an impact on } \\
\text { raising the quality of education }\end{array}$ & 3.40 & 7.4 & 13.3 & 24.2 & 42.5 & 12.6 \\
\hline $\begin{array}{l}\text { 20. Insurers and users (students) can have an impact on } \\
\text { reducing the education fees }\end{array}$ & 3.34 & 8.5 & 15.7 & 23.3 & 38.2 & 14.3 \\
\hline $\begin{array}{l}\text { 21. The competition among educational institutions can be } \\
\text { of benefit to the users (students) }\end{array}$ & 3.41 & 9.6 & 14.6 & 18.4 & 40.1 & 17.3 \\
\hline $\begin{array}{l}\text { 22. The competition among insurers can be to use of users } \\
\text { (students) }\end{array}$ & 3.33 & 8.1 & 16.5 & 23.0 & 39.3 & 13.1 \\
\hline $\begin{array}{l}\text { 23. The insurance companies can be helpful in improving } \\
\text { school and educational standards }\end{array}$ & 3.42 & 7.3 & 13.8 & 22.7 & 42.5 & 13.7 \\
\hline $\begin{array}{l}\text { 24. The insurance companies can restrict the cost of } \\
\text { schooling }\end{array}$ & 3.25 & 9.5 & 17.5 & 24.4 & 35.9 & 12.7 \\
\hline $\begin{array}{l}\text { 25. Meeting all the expenses of education by the insurers } \\
\text { can be of benefit to users (students) }\end{array}$ & 3.48 & 7.9 & 14.2 & 19.2 & 39.3 & 19.5 \\
\hline $\begin{array}{l}\text { 26. Education cost can decrease in school when students } \\
\text { quota is filled }\end{array}$ & 3.34 & 7.9 & 16.1 & 24.8 & 36.7 & 14.5 \\
\hline $\begin{array}{l}\text { 27. Education cost can decrease in school through state } \\
\text { support }\end{array}$ & 3.55 & 7.3 & 12.2 & 17.8 & 44.2 & 18.6 \\
\hline $\begin{array}{l}\text { 28. Education cost can decrease due to competition among } \\
\text { schools }\end{array}$ & 3.28 & 8.7 & 17.5 & 23.6 & 37.2 & 13.0 \\
\hline $\begin{array}{l}\text { 29. Education expenditure can be paid as fixed insurance } \\
\text { payment }\end{array}$ & 3.31 & 8.4 & 15.1 & 26.2 & 37.4 & 12.9 \\
\hline 30. Education expenditure can be paid in small installment & 3.52 & 8.4 & 12.0 & 16.6 & 45.3 & 17.6 \\
\hline $\begin{array}{l}\text { 31. Payment of the installments can be adjusted to } \\
\text { household budget }\end{array}$ & 3.59 & 8.3 & 10.4 & 15.8 & 44.3 & 21.1 \\
\hline $\begin{array}{l}\text { 32. The burden of education cost on the budget can be } \\
\text { eased }\end{array}$ & 3.49 & 8.3 & 12.7 & 19.3 & 41.5 & 18.3 \\
\hline $\begin{array}{l}\text { 33. Insurers can establish better relations between schools } \\
\text { and students }\end{array}$ & 3.28 & 8.5 & 15.4 & 27.4 & 36.7 & 12.0 \\
\hline $\begin{array}{l}\text { 34. In insurance sector, new employment opportunities can } \\
\text { be created }\end{array}$ & 3.32 & 7.3 & 13.3 & 29.9 & 39.2 & 10.3 \\
\hline 35. Education insurance fund can flourish & 3.43 & 6.8 & 11.9 & 25.6 & 42.8 & 12.9 \\
\hline 36. Education with scholarship can flourish & 3.61 & 6.2 & 11.4 & 17.2 & 45.8 & 19.4 \\
\hline $\begin{array}{l}\text { 37. In educational institutions new employment } \\
\text { opportunities can be created }\end{array}$ & 3.39 & 7.1 & 12.0 & 28.0 & 40.6 & 12.2 \\
\hline $\begin{array}{l}\text { 38. New legal amendments can be made to regulate the } \\
\text { Insured Education System }\end{array}$ & 3.39 & 8.2 & 11.9 & 24.4 & 43.4 & 12.1 \\
\hline $\begin{array}{l}\text { 39. The Insured Education System can be protected through } \\
\text { reinsurance }\end{array}$ & 3.33 & 7.5 & 13.2 & 30.5 & 36.1 & 12.7 \\
\hline $\begin{array}{l}\text { 40. The Insured Education System can be protected under } \\
\text { state guarantee }\end{array}$ & 3.58 & 7.0 & 10.3 & 18.8 & 45.0 & 18.8 \\
\hline $\begin{array}{l}\text { 41. The Insured Education System can be of benefit to the } \\
\text { society }\end{array}$ & 3.57 & 8.1 & 10.3 & 17.0 & 45.5 & 19.0 \\
\hline $\begin{array}{l}\text { 42. The Insured Education System can be of benefit to } \\
\text { students }\end{array}$ & 3.66 & 7.7 & 9.4 & 16.3 & 42.8 & 23.8 \\
\hline
\end{tabular}

\section{Conclusions}

This model establishes the basis of an education financing system based on revenues created through Joint Education Investment Account, and/or Education Investment Partnership, which would pay for the current or future financing needs of education. In this way, a sustainable funding for education is made affordable through 
small payments. And in case of death, disability or retirement of the investor, the education costs are continued to be paid without interruption by means of education insurance, pension, or through bursaries and loans granted to the student.

In this way, young prodigies who might miss out on education due to lack of funding can be integrated into the society and the humanity. The model also entails more efficient human resource management, and creates employment, all the while paving the way for development of innovation centers where natural resources are sustainably utilized.

\section{References}

Altunışık, R., Coşkun, R., Bayraktaroğlu, S., \& Yıldırım, E. (2004). Social sciences research methods applied SPSS (Sosyal Bilimlerde Araştırma Yöntemleri SPSS Uygulamalı). University of Sakarya İ̈BF.

Çelikhan, S. (2007). The model of participating, payable, profitable, potent insured education system (4Ps-IESM) (Katılıml1, Ödenebilir, Yararlı, Etkin, Sigortalı Eğitim Sistemi (Köye-SES) Modeli). Gebze Yüksek Teknoloji Enstitüsü (GYTE) No.15.

Çelikhan, S., Ery1lmaz, Y., \& Atasayan, Ö. (1998). From economic angle an effective model: The model of insured local administration. Review of Chamber of Industry, 393, $42-44$.

Erdoğan, İ. (1998). With the using examples research design and statistics methods SPSS (Kullanım Örnekleriyle Araştırma Dizaynı ve Istatistik Yöntemleri). Retrieved from http://www.istatistik.gen.tr

In Scientific Research Computerized Statistics Practices SPSS for Windows. (1995). Eğitim Dizisi: 2 Ocak Yayınları. Turkey: Publication of Ocak.

Özdamar, K. (1997). With the package program statistical data analysis. Faculty of Science, T.C. Anatolia University.

Türkiye İstatistik Kurumu (TUİK) Verileri. (2007). Data of Turkish statistical institute. Retrieved from http://www.tuik.gov.tr

VIII. Beş Yıllık Kalkınma Raporu. (2007). Report of VIII five-year development plan. Retrieved from http://www.dpt.gov.tr 